\title{
Characterization and probiotic potential of lactic acid bacteria isolated from dadiah sampled in West Sumatra
}

\author{
Rinita AMELIA ${ }^{1,2}$, Koshy PHILIP ${ }^{1,3^{*}}$ (D), Yudha Endra PRATAMA ${ }^{4}$, Endang PURWATI ${ }^{5}$
}

\begin{abstract}
Dadiah is a traditional dairy food from West Sumatra. Dadiah is made by fermenting fresh buffalo milk in banana leaves covered bamboo sticks at room temperature for two days. Dadiah is nutritious because it contains lactic acid bacteria (LAB) that have probiotic properties. This study aims to determine the characteristics and biochemical properties of LAB by catalase assay and fermentation type. We identified the LAB found in dadiah using conventional laboratory tests and 16S rRNA sequencing methods and confirmed that the LAB was Lactobacillus fermentum. Gram staining showed that the isolated bacteria were Gram-positive bacilli and the catalase assay and fermentation type showed it to be negative catalase and homofermentative.
\end{abstract}

Keywords: lactic acid bacteria, Dadiah, lactobacillus fermentum, probiotic.

Practical Application: Dadiah, is one of the traditional probiotic dairy foods in West Sumatra that is rich in LAB.

\section{Introduction}

Dadiah, which is made from buffalo milk fermented in bamboo tubes and contains lactic acid bacteria (LAB), is one of the famous probiotic foods in West Sumatra. Lintau Buo Utara is one of the regions in Tanah Datar Regency, West Sumatra, noted for its production of dadiah. Dadiah is an integral part of the food and culture of the Minangkabau people. Dadiah is also a biological asset that can be developed as a family business to support people's health and livelihood. This kind of natural probiotic food from animal proteins should be supported through the improved development of buffalo farms (Purwati et al., 2017; Yuniastiti, 2017; Dadih, 2017). In West Sumatra, there are various types of bamboo that are used to produce dadiah. The inner bamboo wall propagates LAB that will help in the fermentation process of dadiah. Therefore, the type of bamboo determines the quality of dadiah (Purwati et al., 2017).

LAB are groups of cocci- or bacilli-shaped Gram-positive bacteria. They are facultative anaerobes, catalase-negative, motile, do not produce spores, and create lactic acid as a metabolic end-product during carbohydrate fermentation. Probiotic LAB is classified as homofermentative or heterofermentative based on their metabolic pathways. In homofermentative LAB, they ferment sugars to produce mainly lactic acid under anaerobic conditions. In heterofermentative $\mathrm{LAB}$, sugars are fermented to produce ethanol, $\mathrm{CO}_{2}$, and less lactic acid (Ayyash et al., 2018). LAB does not constitute cytochrome and does not form spores. They belong to the order Eubacteriales under Streptococcaceae and Lactobacillaceae families. The genera that comprise LAB are Lactobacillus, Lactococcus, Bifidobacterium, Tetragenococcus, Vagococcus, Weissella, Streptococcus, Leuconostoc, Aerococcus, Oenococcus, Carnobacterium, Enterococcus, Sporolactobacillus, and Pediococcus (Yerlikaya, 2019).

Every dadiah product has different strains of LAB depending on the region of the manufacturer. Each region can use different types of bamboo and buffalo species that produce their milk. Using 16S rRNA sequencing, LAB in dadiah can be identified. For years, the dadiah was known to have natural probiotic properties. This bacterial strain is non-toxic and safe to consume and considered as food-grade microorganism (Saputri et al., 2018). Probiotics are living microorganisms (single or mixed) that are present adequately in our food, as much as $10^{6}$ to $10^{7}$ colony-forming units (CFU) per gram of food (Dwi et al., 2016; Purwati et al., 2017). Commonly, the bacteria are Lactobacillus, Bifidobacterium, Streptococcus, Lactococcus, and Enterococcus. LAB from fermented milk is widely used as probiotics, including Lactobacillus rhamnosus CAN-1, Lactobacillus plantarum, Lactobacillus brevis, Lactobacillus paracasei, Lactobacillus bulin, Streptococcus thermophilus, Lactobacillus fermentum, and Lactobacillus acidophilus. There is an increased number of new findings of nonpathogenic bacteria and yeast that are considered as probiotics and have health benefits (Saputri et al., 2018; Rayavarapu et al., 2019; (Djunaedi, 2007). Furthermore, diet supplemented with yoghurt showed a significant decline in blood cholesterol. LAB in the presence of prebiotics were found to be effective against increased blood lipid profile (Sarfraz et al., 2019). 
LAB is known as food-grade group of microorganisms, generally recognized as safe, and beneficial to health (Suardana \& Suarsana, 2017). LAB that is utilized as probiotics have the following characteristics: nonpathogenic, viable in medium with low $\mathrm{pH}$, able to grow on medium with high-concentrated bile salts, able to be adherent and colonize epithelial cells, have antibacterial activities, and have health benefits (Son et al., 2017). Probiotics are known to have many health benefits, including antioxidant activity (Wang et al., 2017; Tallapragada et al., 2018). Probiotics modulate the microbial composition associated with conditions such as allergies, cancer, diabetes, inflammatory diseases, cardiovascular diseases, and dyslipidemia. In the past decade, the antioxidant activity of LAB and LAB-related products has been frequently reported (Ho et al., 2019).

LAB can also produce antimicrobial compounds besides lactic and acetic acids, diacetyl and bacteriocins antagonistic to a broad spectrum of microorganisms and can inhibit food spoilage and pathogenic bacteria. Those are the reasons why LAB is often used as an alternative to food preservation products. Bacteriocins are antimicrobial peptides produced by bactericidal or bacteriostatic bacteria. Bacteriocins produced by microorganisms does not have any inhibitory effect on the producing organisms. Bacteriocin can also inhibit the growth of contaminant bacteria that cause foodborne diseases.

Therefore, this study aims to identify the LAB isolated from dadiah from Lintau Buo Utara as a potential probiotic and evaluate its antioxidant effects. Dadiah has long been known to have benefits as a natural probiotic. Moreover, the probiotics contained in dadiah from Lintau Buo Utara are considered halal.

\section{Materials and methods}

\subsection{Materials}

Buffalo milk samples were taken from the village of Tanjung Bonai, district of Lintau Buo Utara, Tanah Datar Regency, West Sumatra. The breeders milk the buffaloes early in the day to make the dadiah. Before milking, the farmer first washes the udder. The milk obtained is immediately poured into the prepared bamboo tubes which were then covered with banana leaves. The milk was left for 48 hours at room temperature to ferment naturally. The bamboo used for the container is Gigantochloa asper (Schult) Kurz species usually referred as bamboo rope or Aru by the locals (Figure 1).

\subsection{Macroscopic identification of Dadiah bacterial culture}

De Man-Rogosa-Sharpe (MRS) broth (Merck) enriched media and MRS Agar (Merck) media were prepared. As much as $1 \mathrm{~g}$ of dadiah was dissolved in $9 \mathrm{ml}$ of MRS Broth solution in a test tube and vortexed until homogeneous for the initial $10^{-1}$ dilution of dadiah. Then, the solution was placed into an anaerobic jar and then incubated for 24 hours at $37^{\circ} \mathrm{C}$. After that, $1 \mathrm{ml}(1000 \mu \mathrm{L})$ of the first dilution was taken, added into a test tube with $9 \mathrm{~mL}$ of MRS broth solution and then vortexed until homogeneous for the $10^{-2}$ dilution. This procedure was repeated until the $10^{-9}$ dilution is attained. From the last dilution, $100 \mu \mathrm{L}$ of the sample was taken and spread on the MRS agar media. The inoculum was placed into the anaerobic jar and incubated for 48 hours at

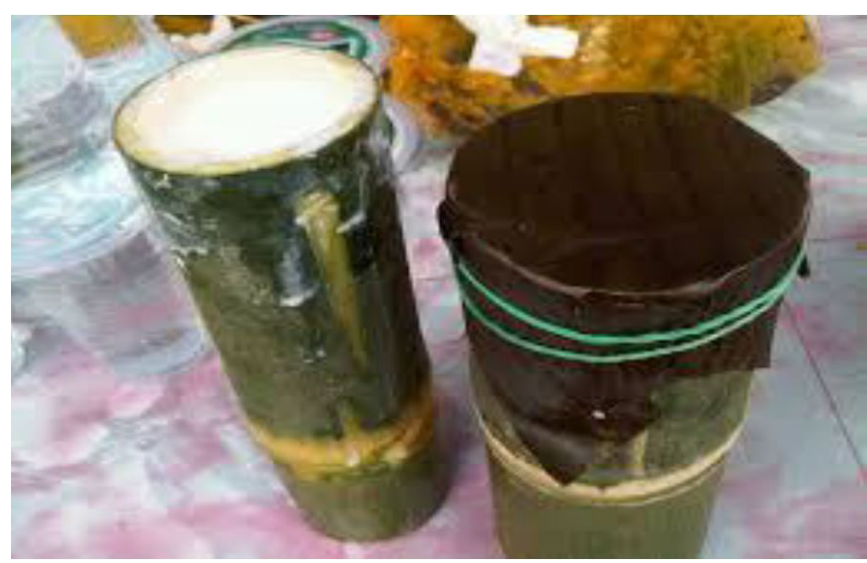

Figure 1. Dadiah from Lintau Buo.

$37^{\circ} \mathrm{C}$. After 48 hours, a single colony of the LAB was observed. The total colony forming units (CFUs) was calculated using the Quebec colony counter (Endang Purwati et al., 2016).

\subsection{Morphology identification of Dadiah bacterial culture}

A loopful of bacterial culture was taken and then placed into a microscopic glass slide. Crystal violet dye was added on to the slide and then left to react for 1 minute. After that, it was rinsed with distilled water and then air-dried. Iodine drops were then added and left to react for 1 minute. Next, the slide was rinsed with distilled water and air-dried before dipping in ethanol for 20 minutes followed by counterstaining with safranin for 30 seconds. The result was observed under the microscope at $400 \times$ magnification.

\subsection{Biochemical properties}

The assay was carried out by inoculating the LAB isolates into $5 \mathrm{~mL}$ of MRS Broth (Merck) contained in test tubes. Durham tubes were inserted in inverted positions and then incubated for 48 hours at $37^{\circ} \mathrm{C}$. Then, the presence or absence of bubbles in the Durham tubes were observed.

\subsection{Acid resistance assay}

Using $9 \mathrm{ml}$ of MRS media broth, $1 \mathrm{ml}$ bacterial culture was inoculated and incubated at $37^{\circ} \mathrm{C}$ for 24 hours with the $\mathrm{pH}$ adjusted to 4 using $5 \mathrm{~N} \mathrm{HCl}$ addition. Furthermore, the dilution was carried out using the spread method to the MRS media and incubated at $37^{\circ} \mathrm{C}$ for 48 hours. The CFU number of the bacteria that survived were calculated. The number of the survived colonies was expressed as $L A B$ viability. The higher the $L A B$ viability, the higher will be the $\mathrm{LAB}$ resilience against acid.

\subsection{Bile salt resistance assay}

One $\mathrm{ml}$ of bacterial culture was inoculated into $9 \mathrm{ml}$ of MRS broth medium and incubated at $37^{\circ} \mathrm{C}$ for 5 hours with $0.5 \%$ bile salt. The mixture was then serially diluted to $10^{-6}$, spread on MRS agar medium and incubated at $37^{\circ} \mathrm{C}$ for 48 hours. The number of bacteria that grew was calculated. The number of colony forming units (CFUs) was expressed as LAB viability count. The higher the $L A B$ viability the higher will be the $L A B$ resilience against bile salt. 


\subsection{Antimicrobial assay}

Antimicrobial activity assays were carried out using the disk diffusion method with Escherichia coli O157, Listeria monocytogenes, and Staphylococcus aureus ATCC 25923 bacteria as test bacteria. One $\mathrm{mL}$ of LAB culture was placed into sterile Eppendorf tubes and then centrifuged at $10000 \mathrm{rpm}$ for 5 minutes. $0.4 \mathrm{~g}$ of nutrient media was prepared (using $20 \mathrm{~g}$ of nutrient agar in $1000 \mathrm{~mL}$ of distilled water). Then $0.2 \%$ enriched bacteria colony was added to the medium and left to culture. The test strains mentioned were assayed for inhibition. Then, $50 \mu \mathrm{L}$ of LAB supernatant was inserted onto the disk. The tested antibiotics were ampicillin $40 \mu \mathrm{L}$, and kanamycin $30 \mu \mathrm{L}$ for controls compared to the supernatant. The petri plates used were then incubated anaerobically at $37^{\circ} \mathrm{C}$. The antibacterial activity was expressed as the diameter of the clear zones of inhibition caused by the antibiotics controls and the LAB supernatant.

\subsection{Identification of LAB using $16 S$ rRNA}

Microbial DNA extraction was conducted using the Promega USA KIT. As much as $1000 \mu \mathrm{L}$ of the single colony from MRS broth containing the LAB isolate was put in a new Eppendorf tube and then centrifuged at 14,000 rpm for 2 minutes. Then the pellet was taken, added with $480 \mu \mathrm{L}$ of $50 \mathrm{mM}$ EDTA and $120 \mu \mathrm{L}$ of Lysozyme. The mixture was incubated in $37^{\circ} \mathrm{C}$ water bath for 60 minutes and then centrifuged for 2 minutes at $14,000 \mathrm{rpm}$. Then the supernatant was removed, the pellet was taken, then $600 \mu \mathrm{L}$ of nuclei lysis solution was added and then homogenized. After that, the mixture was incubated at $80^{\circ} \mathrm{C}$ for 5 minutes. After that, $3 \mu \mathrm{L}$ of RNase Solution was added, homogenized, and incubated in $37^{\circ} \mathrm{C}$ water for 60 minutes. Next, $200 \mu \mathrm{L}$ of Protein precipitation solution was added, vortexed, incubated in ice for 5 minutes, and then centrifuged for 3 minutes at 14,000 rpm. The supernatant was transferred to a new tube and the pellet is removed, added with $600 \mu \mathrm{L}$ isopropanol and homogenized, and then centrifuged for 2 minutes at 14,000 rpm. Then, the pellet and the supernatant were removed, $600 \mu \mathrm{L}$ of $70 \%$ ethanol was added and homogenized, and centrifuged for 2 minutes at 14,000 rpm. Lastly, the pellet was taken and aerated for 15 minutes, and then rehydrated with $50 \mu \mathrm{L}$ of rehydration solution for 30 minutes at $65^{\circ} \mathrm{C}$.

\subsection{Preparation of PCR primary (16S rRNA)}

The R primer (16S-1492R, Tm $47^{\circ} \mathrm{C}, 5^{\prime}$ GTT TAC CTT GTT ACG ACTT-3) and F primer (16S- 27F, Tm $54.3^{\circ} \mathrm{C}$, 5’AGA GTT TGA TCC TGG CTC AG-3) were prepared at 10pM concentrate. The primer was taken at $90 \mu \mathrm{L} \mathrm{dH} 2 \mathrm{O}+10 \mu \mathrm{L}$ of $\mathrm{R}$ and $\mathrm{F}$ primers. The $\mathrm{R}$ and $\mathrm{F}$ primers were dissolved in $\mathrm{TE}$ buffer with $100 \mu \mathrm{M}$ concentrate.

\subsection{Preparation for $16 S$ rRNA gene amplification}

Preparation for $16 \mathrm{~S}$ rRNA gene amplification are based on the primers for $16 \mathrm{~S}$ rRNA (Table 1) and the PCR programme (Table 2).

\subsection{Preparation of $1.5 \%$ agarose for PCR electrophoresis}

As much as 0.6 gram of agarose (obtained from $1.5 \% \mathrm{x}$ $40 \mathrm{~mL}=0.6$ gram) was dissolved in $40 \mathrm{ml}$ of TAE buffer and then heated in a microwave for 30 seconds. After the solution was made lukewarm, 2 ul of redsafe / Gelview was added as a coloring agent. The agar height was about $0.5 \mathrm{~mm}$ and the electrophoresis comb arranged in the agar. The comb was removed after the agar was set.

\subsection{Running gel electrophoresis}

The agar was placed in the electrophoresis apparatus and then added with TAE solution until the agar is immersed. As much as $5 \mu \mathrm{L}$ sample and $5 \mu \mathrm{L}$ DNA ladder were injected into the agar well. The agarose run was set to $100 \mathrm{~V}$ for 40 minutes and the result was seen under the UV light. After the PCR results were read, the amplified DNA was then purified to be sent to Genetika Lab for sequencing.

\subsection{Analysis of sequencing data}

The sequencing data analysis is performed using the DNASTAR software program. For the sequence alignment analysis, the obtained sequences were compared with those already deposited in the GeneBank (http://www.ncbi.nlm.nih.gov) using BLAST (Basic Local Alignment Search Tool). The phylogenetic analysis was done using MEGA v7.0 tools with the Maximum Likelihood and the kimura -2 mode algorithm.

\section{Results and discussions}

\subsection{Macroscopic identification}

The formed single colony from dadiah had these characteristics: round-shaped, slick edges, smooth and convex surface, white-beige color, and $1.8 \mathrm{~mm}$ in diameter. In contrast to probiotics from prato cheese that show brightness color (Silva et al., 2018). The total number of LAB in dadiah was $7.1 \times 10^{10} \mathrm{CFU} / \mathrm{ml}$

Table 1. The primer $16 \mathrm{~S}$ rRNA.

\begin{tabular}{lc}
\hline \multicolumn{1}{c}{ Composition } & Volume \\
\hline Master Mix PCR & $12.5 \mu \mathrm{L}$ \\
Primer F & $1.0 \mu \mathrm{L}$ \\
Primer R & $1.0 \mu \mathrm{L}$ \\
$\mathrm{dH}_{2} \mathrm{O}$ & $9.5 \mu \mathrm{L}$ \\
& $24.0 \mu \mathrm{L}$ \\
DNA & $1.0 \mu \mathrm{L}$ \\
Total number & $25.0 \mu \mathrm{L}$ \\
\hline
\end{tabular}

Table 2. The PCR programme.

\begin{tabular}{lcc}
\hline Stages & Temperature & Time \\
\hline Pre denatured & $95^{\circ} \mathrm{C}$ & 2 minutes \\
Denatured & $95{ }^{\circ} \mathrm{C}$ & 45 seconds \\
Anneling & $56^{\circ} \mathrm{C}$ & 45 seconds \\
Extention & $72{ }^{\circ} \mathrm{C}$ & 1 minute 40 seconds \\
Final extention & $72{ }^{\circ} \mathrm{C}$ & 10 minutes \\
Cooling & $4{ }^{\circ} \mathrm{C}$ & $\sim$ \\
\hline
\end{tabular}


(Table 1). According to Suryono (2003), a good quality dadiah contains more than $10^{6}-10^{8} \mathrm{CFU} / \mathrm{g}$ of LAB. According to the FAO/WHO (Food and Agriculture Organization of the United Nations, 2001), dadiah as a probiotic food should contain $10^{6}-10^{8} \mathrm{CFU} / \mathrm{g}$ of LAB (Table 3 ).

This study has compared LAB research on kefir produced from fresh milk's fermentation by adding kefir grains as carrier ingredients for probiotic organisms with an indigenous source of LAB. It suggests that kefir can be used for fortification with probiotics. The population of bacteria in kefir ranged between $6.4 \times 10^{4}$ and $8.5 \times 10^{8} \mathrm{CFU} / \mathrm{g}$ (Mitra \& Ghosh, 2020). Others, shown the color

\subsection{Morphology identification}

From the gram staining, LAB from dadiah showed the rod-shaped Gram-positive bacteria. According to Purwati et al. (2017), the LAB in dadiah could be cocci or bacilli. The result was observed under the microscope with a magnification of

Table 3. Macroscopic identification.

\begin{tabular}{cccccc}
\hline Sample & Color & Shape & $\frac{\text { Size }}{(\mathrm{mm})}$ & Surface & $\frac{\text { Total LAB Count }}{(\mathrm{CFU} / \mathrm{ml})}$ \\
\hline Dadiah & $\begin{array}{c}\text { White- } \\
\text { beige }\end{array}$ & Round & 1.8 & $\begin{array}{c}\text { Smooth, } \\
\text { convex }\end{array}$ & $7.1 \times 10^{10} \mathrm{CFU} / \mathrm{mL}$. \\
\hline
\end{tabular}

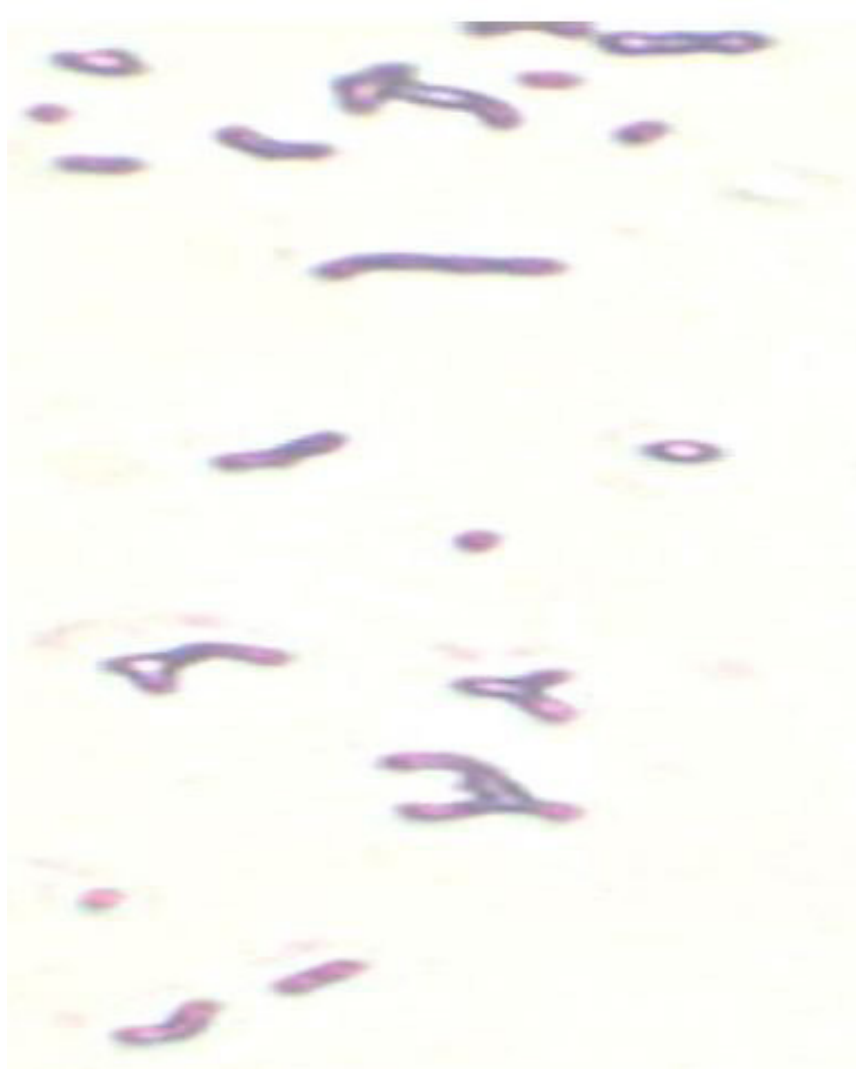

$400 \times$ (Figure 2). Gram-positive, catalase-negative, cocci, and rod-shaped $L A B$ were defined and tested for growth at different temperatures $\left(15^{\circ} \mathrm{C}\right.$ and $45^{\circ} \mathrm{C}$ ) (Bostan et al., 2017)

\subsection{Biochemical properties}

The results showed no presence of bubbles in the Durham tubes placed in broth inoculated with the LAB to confirm its homofermentative characteristic. The genus Lactobacillus consists of 70 species that are grouped into three subgroups, mostly homofermentative or heterofermentative. In general, Lactobacillus is resistant to acids compared to other LAB. From the catalase assay, it was obtained that the LAB isolate in this study does not produce catalase. Ibrahim et al. (2015) reported about LAB identification from mango had a negative result in catalase assay, which means that LAB do not produce the catalase enzyme to transform hydrogen peroxide into water and oxygen. It also indicates that LAB need only slight oxygen to live. LAB constitutes a diverse group of Gram-positive, catalase-negative bacteria that produce lactic acid as the primary end-product of carbohydrate fermentation (Table 4).

\subsection{Acid resistance assay}

Bron et al. (2004) explained that probiotic bacteria is exposed to the stomach acidity when consumed. Hence acid resistance assay was performed on dadiah $\mathrm{LAB}$ at $\mathrm{pH} 4$ and 3. The number

\footnotetext{
Figure 2. Gram staining of lactic acid bacteria.
} 
of colonies that grew on the control was higher $\left(7 \times 10^{8} \mathrm{CFU} / \mathrm{L}\right.$ than the $\mathrm{pH} 3\left(4 \times 10^{8} \mathrm{CFU} / \mathrm{ml}\right)$, with a survival rate of $57.1 \%$ (Table 5). The viability value varies depending on the type of bacteria that survive at a low $\mathrm{pH}$ and depending on the bacterial strain.

\subsection{Bile salt resistance assay}

In addition to acid resistance, $\mathrm{LAB}$ resistance to bile salts is required by probiotics. The $0.5 \%$ concentration is high enough to select a strain that is resistant to bile salts (Gilliland \& Walker, 1990). The results showed $24 \times 10^{8} \mathrm{CFU}$ of cell count in control and reduced to $16 \times 10^{8} \mathrm{CFU}$ after $0.5 \%$ bile salts addition, so the LAB viability was $66.7 \%$ (Table 5 ).

\subsection{Antimicrobial activity}

The results showed that the widest inhibition zone was observed with E. coli $(23.28 \mathrm{~mm})$, followed by L. monocytogenes $(12.12 \mathrm{~mm})$, and then $S$. aureus $(7.63 \mathrm{~mm})$. The results of this study have a higher inhibition zone than that of Syukur \& Fachrial (2014), where the dadiah from Solok had $\pm 12 \mathrm{~mm}$ inhibition zone against $E$. coli. Antimicrobial effect of the LAB from dadiah against pathogenic bacteria showed significance.

The results showed that LAB from dadiah also had high inhibitory effect on E. coli compared to kanamycin and ampicillin (Table 6). Following Morales et al. (2003) study, the zone of inhibition is grouped into four categories, weak $(<5 \mathrm{~mm})$, medium $(5-10 \mathrm{~mm})$, strong $(>10-20 \mathrm{~mm})$, and very strong ( $>20-30 \mathrm{~mm}$ ). Thus, the dadiah LAB inhibition activity towards $E$. coli is categorized as very strong. In another study, L. acidophilus from fermented milk has been tested to have an antimicrobial effect on bacteria such as E. coli and S. aureus (Shafi et al., 2019). Potential LAB in Kefir grains obtained from brown sugar promotes antimicrobial activity by developing a halo zone of inhibition corresponding to $35 \mathrm{~mm}, 14 \mathrm{~mm}, 12 \mathrm{~mm}$,

Table 4. Biochemical test of Dadiah.

\begin{tabular}{lc}
\hline \multicolumn{1}{c}{ Biochemical Test } & Result \\
\hline Catalase Test & Negative $(-)$ \\
Type of Fermentation & Homofermentative \\
\hline
\end{tabular}

Table 5. Acid resistance and bile salt resistance.

\begin{tabular}{lcc}
\hline \multicolumn{1}{c}{ Resistance Test } & Control & Viability \\
\hline Acid Resistance & $7 \times 10^{8} \mathrm{CFU}$ & $4 \times 10^{8} \mathrm{CFU}$ \\
Bile Salt Resistance & $24 \times 10^{8} \mathrm{CFU}$ & $16 \times 10^{8} \mathrm{CFU}$ \\
\hline
\end{tabular}

Table 6. Antimicrobial activity of Dadiah LAB.

\begin{tabular}{lccc}
\hline \multirow{2}{*}{$\begin{array}{c}\text { Inhibitory } \\
\text { Source }\end{array}$} & E. coli $\mathrm{O} 157$ & S. aureus & $\begin{array}{c}\text { T. } \\
\text { monocytogenes }\end{array}$ \\
\cline { 2 - 4 } Dadiah & 23.28 & 7.63 & 12.12 \\
Kanamycin & 11.16 & 5.00 & 5.10 \\
Ampicillin & 13.68 & 10.15 & 7.63 \\
\hline
\end{tabular}

$14 \mathrm{~mm}$ and $14 \mathrm{~mm}$ for C. albicans, S. typhi, S. sonei, S. Aureus, and E. coli (Açik et al., 2020).

\subsection{Molecular identification by $16 S$ rRNA Methods}

The results of PCR sequencing are presented in Figure 3 below. The results indicate that the amplified DNA was $1540 \mathrm{bp}$ and the specific primer used in this study was able to identify the bacteria. The $16 \mathrm{~S}$ rRNA gene is universally distributed and has a rational measure for sequence analysis (Vaughan et al., 2000).

Based on the PCR results and BLAST analysis, the isolated bacteria from dadiah had $99.99 \%$ similarity with L. fermentum (Figure 4). A study by Syukur \& Fachrial (2014) obtained the

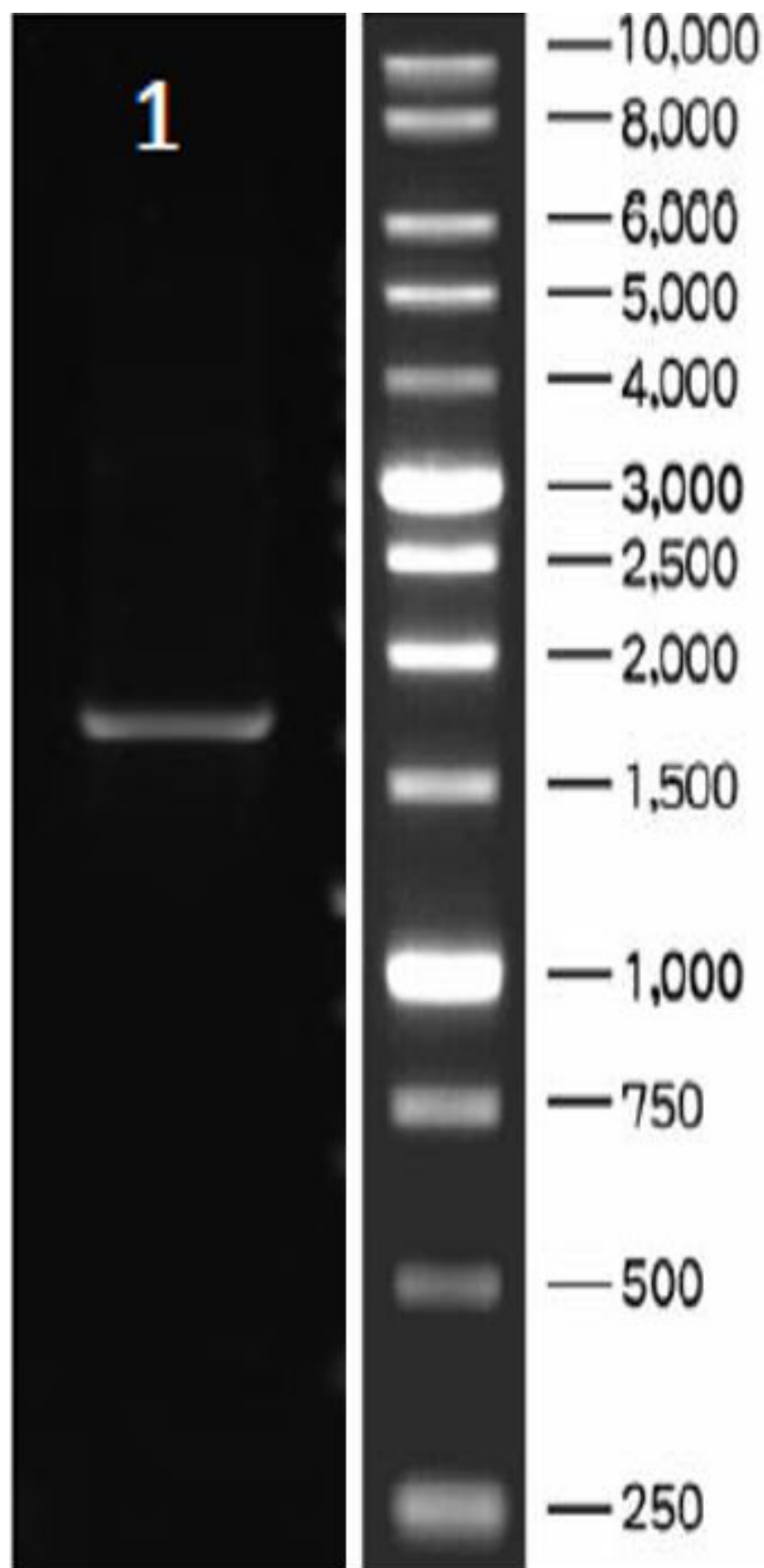

Figure 3. PCR sequencing results (isolate 1). 


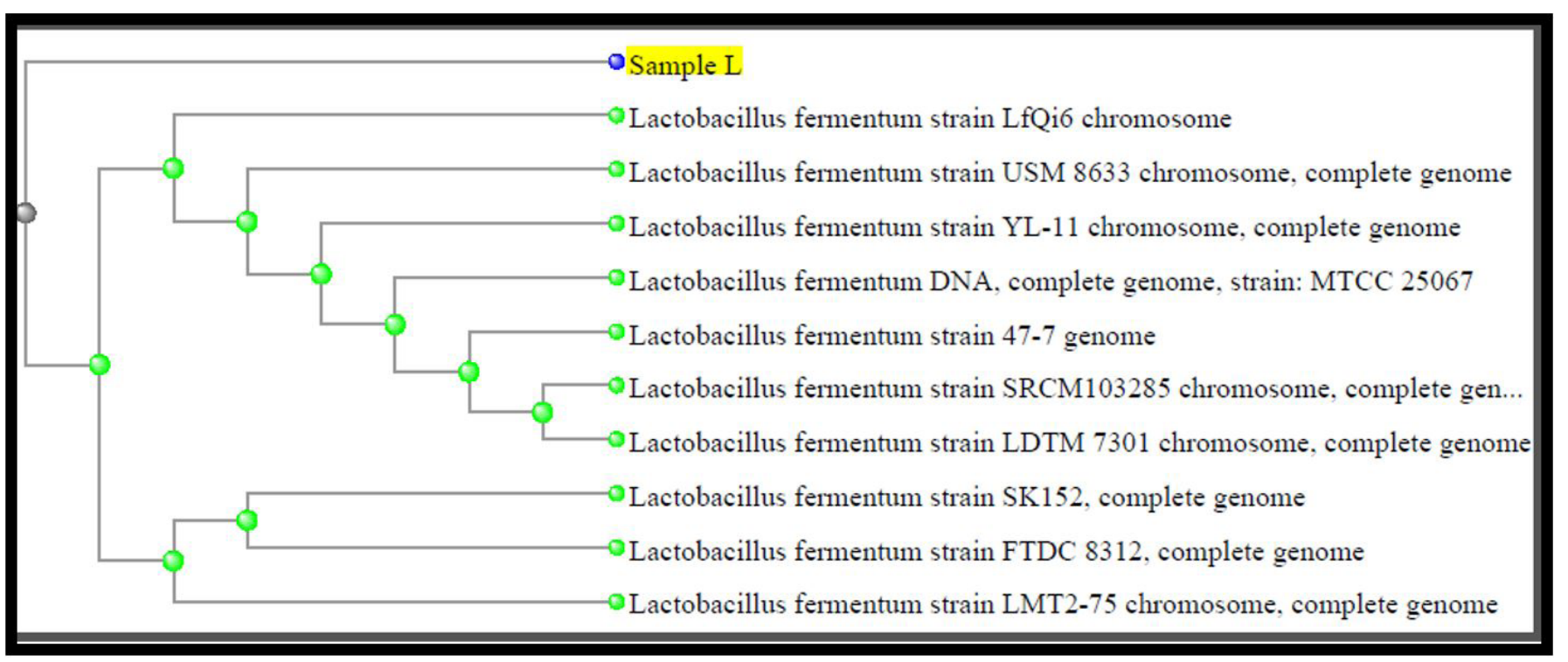

Figure 4. Phylogenic tree sample L in dadiah from Lintau Buo.

L. plantarum bacteria isolated from dadiah from Sijunjung, showed the DNA sequence was $1525 \mathrm{bp}$. Likewise, in the study conducted by Purwati et al., (2018), the isolation and characteristics analysis of $\mathrm{LAB}$ from the dadiah also obtained $L$. plantarum strain Dad-13 with a similarity value of $97 \%-100 \%$ using BLAST analysis (Purwati et al., 2018). The study by Melia et al. (2018) on buffalo milk samples from the Agam district (BMA 3.3) showed the LAB as a strain of $L$. fermentum (L23) using BLAST analysis. Wirawati et al. (2019) reported sequence results in dadiah from two different regions of West Sumatra that showed 41.6\% (five isolates) were identified as Lactococcus lactis ssp. lactis, 25\% (three isolates) identified as Lactobacillus plantarum ssp. plantarum, $16.6 \%$ (two isolates) identified as L. lactis ssp. cremoris, and 8.3\% (one isolate each) identified as Pediococcus pentosaceus and Lactobacillus pentosus (Wirawati et al., 2019). This study is in line with the study by Sukma et al. (2017), wherein the LAB in dadiah was dominated by bacteria from the Lactococcus, Lactobacillus, and Leuconostoc groups.

\section{Conclusion}

Dadiah, is one of the traditional probiotic dairy foods in West Sumatra that is rich in LAB. The isolated LAB from dadiah has the potential as a natural probiotic, nonpathogenic, viable in medium with low $\mathrm{pH}$ and high-concentrated bile salts and have antibacterial activities. Molecular and bioinformatics analysis showed that the LAB in dadiah is L. fermentum which has antioxidant properties and health benefits and additional therapy to overcome adverse effects of antibiotics in the gastrointestinal tract.

\section{Acknowledgment}

This research supported by the Laboratory of Animal Husbandry Biotechnology/Technology Animal Product, Andalas University. The authors would like to thank Hibah Klaster Guru Besar 2020, team leader: Prof. drh. Hj. Endang Purwati, MS, $\mathrm{PhD}$ and $\mathrm{PhD}$ Supervisor Prof. Dr. Koshy Philip

\section{References}

Açik, M., Çakiroğlu, F. P., Altan, M., \& Baybo, T. (2020). Alternative source of probiotics for lactose intolerance and vegan individuals: sugary kefir. Food Science and Technology, 40(3), 523-531. http:// dx.doi.org/10.1590/fst.27919.

Ayyash, M., Al-dhaheri, A. S., Al Mahadin, S., Kizhakkayil, J., \& Abushelaibi, A. (2018). In vitro investigation of anticancer, antihypertensive, antidiabetic, and antioxidant activities of camel milk fermented with camel milk probiotic: A comparative study with fermented bovine milk. Journal of Dairy Science, 101(2), 1-12. http://dx.doi. org/10.3168/jds.2017-13400. PMid:29224862.

Bostan, K., Unver Alcay, A., Yalçin, S., Eren Vapur, U., \& Nizamlioglu, M. (2017). Identification and characterization of lactic acid bacteria isolated from traditional cone yoghurt. Food Science and Biotechnology, 26(6), 1625-1632. http://dx.doi.org/10.1007/s10068-017-0222-z. PMid:30263699.

Bron, P. A., Grangette, C., Mercenier, A., Vos, W. M., Kleerebezem, M., Al, B. E. T., \& Acteriol, J. B. (2004). Identification of Lactobacillus plantarum genes that are induced in the gastrointestinal tract of mice. Journal of Bacteriology, 186(17), 5721-5729. http://dx.doi. org/10.1128/JB.186.17.5721-5729.2004. PMid:15317777.

Dadih, M. (2017). Karakteristik dan Pengembangan Dadih dari Susu Sapi sebagai Alternatif Dadih Susu Kerbau. Wartazoa, 27(2), 95-103.

Djunaedi, D. (2007). Pengaruh Probiotik Pada Respon Imun. Jurnal Kedoteran Brawijaya, 23(1), 22-27. http://dx.doi.org/10.21776/ ub.jkb.2007.023.01.4.

Dwi, M., Wijayanti, S., \& Thohari, I. (2016). Kualitas dadih susu kambing yang diinkubasi pada berbagai macam bambu. Jurnal Ilmu dan Teknologi Hasil Ternak, 11(1), 22-37.

Endang Purwati RN, Aritonang, S. N., Melia, S., Juliyarsi, I., \& Purwanto, H. (2016). Manfaat Probiotik Bakteri Asam Laktat Dadiah Menunjang Kesehatan Masyarakat. Sumatera Barat, Indonesia: Andalas University.

Food and Agriculture Organization of the United Nations - FAO / World Health Organization - WHO (2001). Joint Expert Consultation on Evaluation of Health and Nutritional Properties of Probiotics in Food including Powder Milk with Live Lactic Acid Bacteria. Argentina: $\mathrm{FAO} / \mathrm{WHO}$. 
Gilliland, S. E., \& Walker, D. K. (1990). Factors to consider when selecting a culture of Lactobacillus acidophilus as a dietary adjunct to produce a hypocholesterolemic effect in humans. Journal of Dairy Science, 73(4), 905-911. http://dx.doi.org/10.3168/jds.S00220302(90)78747-4. PMid:2111831.

Ho, S., Hsieh, Y., Wang, S., \& Chen, M. (2019). Improving effect of a probiotic mixture on memory and learning abilities in $\mathrm{d}$-galactose - Treated aging mice. Journal of Dairy Science, 102(3), 1-9. http:// dx.doi.org/10.3168/jds.2018-15811. PMid:30639021.

Ibrahim, A, Fridayanti, A., \& Delvia, F. (2015). Isolasi Dan Identifikasi Bakteri Asam Laktat (BAL) Dari Buah Mangga (Mangifera Indica L.). Jurnal Ilmiah Manuntung, 1(2), 159-163.

Melia, S., Yuherman, Y., Jaswandi, J., \& Purwati, E. (2018). Selection Of Buffalo Milk Lactic Acid Bacteria With Probiotic Potential. Asian J Pharm Clin Res, 11(6), 186-189. http://dx.doi.org/10.22159/ ajpcr.2018.v11i6.24809.

Mitra, S., \& Ghosh, B. C. (2020). Quality characteristics of kefir as a carrier for probiotic Lactobacillus rhamnosus GG. International Journal of Dairy Technology, 73(2), 384-391. http://dx.doi.org/10.1111/14710307.12664.

Morales, G., Sierra, P., Mancilla, A., Paredes, L.A.L., Gallardo, O., \& Borquez, J. (2003). Secondary metabolites from four medicinal plants from Northern Chile, antimicrobial activity, and biotoxicity against Artemia salina. J. Chile Chem, 48(2), 13-18.

Purwati, E., Hellyward, J., \& Purwanto, H. (2018). Isolation, characterization and identification of DNA's lactic acid bacteria (Lab) of Dadih Lintau (Tanah Datar District). Which Is Antibiotic Resistance., 2, 28-31.

Purwati, E., Yellita, Y. S. M., \& Hartini, P. (2017). Aplikasi Bioteknologi Bakteria Asam Laktik dan Bakteriosin Isolasi dari susu kerbau dan dadih untuk menurunkan kolesterol, pengawet bahan makanan, kosmetik dan energi (Dissertation). Universitas Andalas: Padang, West Sumatera, Indonesia.

Rayavarapu, B., Tallapragada, P., \& Road, M. (2019). Evaluation of potential probiotic characters of Lactobacillus Fermentum. Food and Nutrition Sciences, 20(2), 183-197.

Saputri, F. A., Kang, D., Kusuma, A. S. W., Rusdiana, T., Hasanah, A. N., \& Abdulah, R. (2018). Lactobacillus plantarum IS-10506 probiotic administration increases amlodipine absorption in a rabbit model. The Journal of International Medical Research, 46(12), 5004-5010. http://dx.doi.org/10.1177/0300060518788994. PMid:30092663.

Sarfraz, F., Farooq, U., Shafi, A., Hayat, Z., Akram, K., \& Rehman, H. U. (2019). Hypolipidaemic effects of synbiotic yoghurt in rabbits. International Journal of Dairy Technology, 72(4), 545-550. http:// dx.doi.org/10.1111/1471-0307.12618.

Shafi, A., Naeem Raja, H., Farooq, U., Akram, K., Hayat, Z., Naz, A., \& Nadeem, H. R. (2019). Antimicrobial and antidiabetic potential of synbiotic fermented milk: A functional dairy product. International Journal of Dairy Technology, 72(1), 15-22. http://dx.doi. org/10.1111/1471-0307.12555.
Silva, H. L. A., Balthazar, C. F., Silva, R., Vieira, A. H., Costa, R. G. B., Esmerino, E. A., Freitas, M. Q., \& Cruz, A. G. (2018). Sodium reduction and flavor enhancer addition in probiotic prato cheese: Contributions of quantitative descriptive analysis and temporal dominance of sensations for sensory profiling. Journal of Dairy Science, 101(10), 8837-8846. http://dx.doi.org/10.3168/jds.201814819. PMid:30077456.

Son, S., Jeon, H., Bi, E., Lee, N., Park, Y., Kang, D., \& Paik, H. (2017). Potential probiotic Lactobacillus plantarum Ln 4 from kimchi: Evaluation of $b$ -galactosidase and antioxidant activities. Lebensmittel-Wissenschaft + Technologie, 85, 181-186. http://dx.doi.org/10.1016/j.lwt.2017.07.018.

Suardana, I. W., \& Suarsana, I. N. (2017). Karakterisasi Fisikokimia dan Uji Aktivitas Bakteriosin dari Bakteri Asam Laktat Isolat 13 B Hasil Isolasi Kolon Sapi Bali. Indonesia Medicus Veterinus, 6(4), 278-287. https://doi.org/10.19087/imv.2017.6.4.278

Sukma A, Tah, H., Tien, N.T.T., Fitria, N., Mimura, I., Kaneko, R., Arakawa1, K., \& Morita, H. (2017). Microbiota community structure in traditional fermented milk dadiah in Indonesia: Insights from high-throughput $16 \mathrm{~S}$ rRNA gene sequencing. Milk Science International, 70, 20-22.

Suryono. (2003). Dadih: Produk Olahan Susu Fermentasi Tradisional yang Berpotensi sebagai Pangan Probiotik. Pengantar Falsafah Sains, Program Pascasarjana Institut Pertanian Bogor, Bogor.

Syukur, S., \& Fachrial, E. (2014). Isolation, antimicrobial activity and protein bacteriocin characterization of lactic acid bacteria isolated from Dadih in Solok, West Sumatera. Research Journal of Pharmaceutical, Biological and Chemical Sciences, 5(1096), 1096-1104.

Tallapragada, P., Rayavarapu, B., Rao, P. P., \& Ranganath, N. N. (2018). Screening of potential probiotic lactic acid bacteria and production of amylase and its partial purification. Journal of Genetic Engineering and Biotechnology, 16(2), 357-362. http://dx.doi.org/10.1016/j. jgeb.2018.03.005. PMid:30733746.

Vaughan, E. E., Schut, F., Heilig, H. G. H. J., Zoetendal, E. G., de Vos, W. M., \& Akkermans, A. D. L. (2000). A molecular view of the intestinal ecosystem. Current Issues in Intestinal Microbiology, 1(1), 1-12. PMid:11709849.

Wang, Y., Wu, Y., Wang, Y., Xu, H., Mei, X., Yu, D., Wang, Y., \& Li, W. (2017). Antioxidant properties of probiotic bacteria. Nutrients, 9(5), 521.

Wirawati, C. U., Sudarwanto, M. B., Lukman, D. W., Wientarsih, I., \& Srihanto, E. A. (2019). Diversity of lactic acid bacteria in dadih produced by either back-slopping or spontaneous fermentation from two different regions of West Sumatra, Indonesia. Veterinary World, 12(6), 823-829. http://dx.doi.org/10.14202/vetworld.2019.823-829. PMid:31440000.

Yerlikaya, O. (2019). Probiotic potential and biochemical and technological properties of Lactococcus lactis ssp. lactis strains isolated from raw milk and kefir grains. Journal of Dairy Science, 102(1), 1-11. http:// dx.doi.org/10.3168/jds.2018-14983. PMid:30391179.

Yuniastiti, A. (2017). PROBIOTIK (Dalam Perspektif Kesehatan) (p. 100). Semarang: UNNES Press. 